\title{
PEMBUATAN ABON DAGING SAPI HYGIENIS DI KELURAHAN DARMO KOTA SURABAYA JAWA TIMUR
}

\author{
Samsul Huda ${ }^{1)}$, Siti Naviah ${ }^{2)}$ \\ ${ }^{1,2}$ Fakultas Pertanian/Perikanan Universitas Dr. Soetomo Surabaya \\ Email: samsul_huda_mr@yahoo.com, samsulhuda@unitomo.ac.id
}

\begin{abstract}
Abstrak
Abon merupakan produk olahan dari daging sapi, prosesnya pembuatannya sederhana melalui tahapan awal adalah daging disuwir-suwir kemudian dimasak hingga menjadi abon. Usaha ini bisa dilakukann secara sederhana dengan berbagai kreasi, permasalahannya adalah kualitas mutu (hygienis) dan bidang manajemen. Tujuan kegiatan adalah memberikan solusi alternatif terhadap beberapa permasalahan yang dihadapi oleh produsen agar dapat berkembang dan mampu bersaing dengan industri-industri besar makanan ringan lainnya serta ketersediaan tenaga kerja terampil yang berkesinambungan. Lokasi pengabdian ditentukan seara purposive dikelurahan darmo/Kecamatan Wonokromo Surabaya sebagai tempat mitra pengusaha abon serta tenaga kerja ibu ibu setempat. Hasil pengabdian ini menyimpulkan bahwa pada tahapan produksi yang perlu diperhatikan adalah mutu bahan baku, karena mempengaruhi mutu hasil akhir abon, pada produksi jumlah banyak diperlukan teknologi mesin suwir. Secara menejemen balik modal diperlukan selama 2 bulan, dengan nilai tambah produksi abon sebesar Rp.73.333.33/kg
\end{abstract}

Kata kunci: Abon, Kualitas mutu, daging sapi

\begin{abstract}
Shredded is a processed product from beef, the process of making it simple through the initial stages is the meat is shredded and then cooked until it becomes shredded. This effort can be done simply with various creations, the problem is quality (hygienic) and management. The aim of the activity is to provide alternative solutions to some of the problems faced by producers in order to develop and be able to compete with other major snack industries and the availability of a sustainable skilled workforce. The location of the service was determined purposively in the darmo I Wonokromo sub-district of Surabaya as the place for the abon business partners and the local maternal labor. The results of this dedication concluded that at the production stage that needs to be considered is the quality of raw materials, because it affects the quality of the abon final product, in the production of large quantities required shredder machine technology. In return, management capital is needed for 2 months, with the added value of shredded production of Rp. $73,333.33 / \mathrm{kg}$
\end{abstract}

Keywords: Abon, Quality, beef

\section{PENDAHULUAN}

\section{Analisis Situasi}

Kelurahan Darmo Kota Surabaya tepatnya Jl. Cisedane 18 Kota Surabaya terdapat Usaha Industri Rumah Tangga (IRT) Abon daging sapi. Mereka menggantungkan hidupnya dari jenis usaha ini. Pada wilayah tersebut terdapat satu Industri Rumah Tangga (IRT) yang memperkerjakan 5 orang tenaga kerja baik tenaga tetap maupun borongan.
Keberadaannya perlu dipertahankan karena daerah sekitarnya juga terdapat pula kelompok pembuat abon, meskipun bekerja secara sendiri sendiri, sehingga tahapan berikutnya perlu dikembangkan agar mempunyai posisi yang lebih kuat untuk ikut membangun perekonomian setempat.

Kegiatan PK-MTP yang dilakukan oleh Tim pelaksana diarahkan untuk memberikan solusi alternatif terhadap beberapa 
permasalahan yang dihadapi oleh IRT Abon daging Sapi Kota Surabaya agar dapat berkembang dan mampu bersaing dengan industri-industri besar makanan ringan lainnya serta ketersediaan tenaga kerja terampil yang berkesinambungan.

\section{Permasalahan Mitra}

Berdasarkan hasil identifikasi dan analisis situasi didapatkan beberapa permasalahan yang perlu segera dicara solusi alternatifnya yaitu :

a. Permasalahan kualitas mutu (hygienis) dan kuantitas produksi.

Pada IRT tersebut proses penggorengan dan penirisan serta penyuwiran dilakukan secara manual dengan tenaga kerja harian, sehingga kondisi tersebut sangat mempengaruhi performance produk.

b. Permasalahan bidang manajemen.

Permasalahan manajemen yang paling menonjol pada produsen (IRT) tersebut adalah job deskripsi dan pengelolaan keuangan dalam usahanya tersebut. Padahal dengan adanya laporan keuangan akan memungkinkan pemilik memperoleh data dan informasi yang tersusun secara sistematis. Adanya laporan keuangan, pemilik dapat memperhitungkan keuntungan yang diperoleh, mengetahui berapa tambahan modal yang dicapai, dan juga dapat mengetahui bagaimana keseimbangan hak dan kewajiban yang dimiliki. Sehingga setiap keputusan yang diambil oleh pemilik dalam mengembangkan usahanya termasuk kebutuhan tenaga kerja didasarkan pada kondisi konkret keuangan yang dilaporkan secara lengkap bukan hanya didasarkan pada asumsi semata. Terhadap kondisi umum usaha pada usaha produksi abon sapi ini dapat diprediksikan akan terus

berkembang jika dilihat jumlah produk yang dihasilkan dan kebutuhan bahan baku mengalami peningkatan dan konsumen yang terus berdatangan. Kondisi tersebut menuntut kualitas (hygienis) dan jaminan mutu produk yang konsisten dan berdaya saing, oleh karena itu melalui usulan program PK-MTP diupayakan untuk memberikan solusi alternatif terhadap beberapa masalah yang telah diidentifikasi.

\section{METODE PELAKSANAAN}

Secara kongkrit dari solusi yang ditawarkan diaplikasikan dalam beberapa bentuk kegiatandiantaranya :

\section{Diskusi dan Penyamaan presepsi}

Diskusi antara tim pelaksana dengan mitra untuk penyamaan presepsi dalam mencari solusi dari permasalahan yang telah teridentifikasi. Hal ini dimaksudkan untuk menghindari konflik apabila solusi alternatif diimplementasikan.

Membuat desain mesin penggorengan dan penirisan serta mesin pencacah/suwir daging sapi.

\section{Membuat disain alat}

Membuat alat sesuai dengan disain yang telah ditetapkan. Fokus pada sistem penggorengan dan penirisan serta mesin pencacah/suwir daging sapi sehingga didapatkan produk abon yang efisien dalam waktu, seragam dan higienis.

\section{Pelatihan,pendampingan manajerial.}

bidang

Selama proses usahanya berlangsung tidak pernah melakukan pencatatan transaksinya ke dalam jurnal umum. Catatan dilakukan secara tradisional dan sangat sederhana dengan mendeskripsikan setiap transaksi yang terjadi dan diteruskan pada pembuatan neraca lajur atau kertas lerja atau worksheet. Oleh karena itu dilakukan pelatihan dan pendampingan tentang : Cara merancang dan menyajikan pembuatan akun dan penomoran berdasarkan transaksitransaksi yang terjadi.

Dalam melaksanakan program ini dibutuhkan partisipasi mitra. Bentuk 
partisipasi mitra tersebut antara lain ádalah: Bersedia berdiskusi dan berpartisipasi akatif bersama tim pelaksana dalam pelaksanaan program pelatihan dan pendampingan. Ikut memberikan saran dan masukan dalam mendesain alat. Ikut serta dalam uji coba dan demonstrasi alat dengan menyiapkan sarana dan prasarana yang dimiliki mitra tempat demonstrasi. Menyiapkan tenaga kerja untuk dilatih dalam pemakaian dan pengoperasian alat. Bersedia bekerjasama secara berkelanjutan.

\section{HASIL DAN LUARAN YANG DICAPAI}

Kelurahan darmo Kecamatan Wonokromo Surabaya merupakan salah satu kabupaten di Jawa Timur dengan posisi jarak dari kampus ke lokasi Mitra 5,8 km dengan waktu tempuh 17 menit. Pada lokasi ini terdapat 1 (satu) mitra yang terlibat semuanya bergerak pada produk yang sama yaitu "Abon". Keberadaanya mempunyai kontribusi terhadap perekonomian setempat serta berperan penting dalam hal penciptaan tenaga kerja utamanya warga sekitar berkelanjutan.

\section{Hasil}

Berdasarkan dari tujuan awal Program Pengabdian Pada masyarakat ini adalah menciptakan dan membina tenaga kerja terampil dengan mengoptimalkan tenaga kerja warga sekitar sehingga berdampak pada perekonomian setempat. Secara rinci proses pendampingan tersebut sebagai berikut :

\section{Proses Produksi}

Tahapan proses produksi dimulai dari persiapan bahan baku utama abon yaitu daging sapi segar, kenyataan di lapangan memang belum ada jaminan mengenai mutu bahan baku yang digunakan, sehingga pada pendampingan dan penyuluhan ini dikenalkan dan dijelaskan bagaimana pengaruhnya terhadap hygienis dan mutu akhir abon yang dihasilkan. Tahap pertama adalah daging di potong potong kecil tanpa lemak dan jaringan ikat dan dibersihkan hingga tidak ada darah yang tersisa, selanjutnya direbus dalam air mendidih selama 1 (satu) jam. Selanjutnya dilakukan proses suwir daging, proses ini dilakukan secara manual, karenanya diperkenalkan proses suwir daging dengan menggunakan mekanik. Setelah proses tahapan bahan baku, kemudian dilanjutkan dengan persiapan bumbu bumbu untuk memberikan aroma sebagai ciri khas abon sesuai target sasaran konsumen yang dituju, dalam hal ini sasarannya adalah anak anak, sehingga rasa abon dibuat tidak begitu pedas. Adapun rincian bumbu bumbu tersebut sebagai berikut : ketumbar halus $25 \mathrm{~g}$, glukosa $300 \mathrm{~g}$ berperan penting dalam rasa (Dinh, et al 2018), kemiri $100 \mathrm{~g}$, bawang merah $125 \mathrm{~g}$, bawang putih $50 \mathrm{~g}$, garam secukupnya selain rasa juga berkontribusi terhadap daya ikat air dan lemak (Poulanne et al, (2001), semua bumbu haluskan, kemudian tumis dengan sedikit minyak goreng di atas wajan, untuk tambahan sebagai penyedap aroma abon bisa ditambahkan lengkuas, jahe, kunyit, asam jawa dan penyedap. Jenis bahan pengisi yang berbeda berpengaruh terhadap kandungan protein dan serat abon Susansi, dkk (2016). Sedangkan interaksi terhadap bahan substitusi dan perbandingan yang berbeda berpengaruh terhadap kadar protein, rasa, warna dan tektur abon daging sapi (Wahyuni, 2015. Tahapan selanjutnya tambahkan santan kelapa dan daging yang telah di suwir aduk rata dan panaskan diatas kompor hingga kering dan tiriskan diatanya. Selanjutnya panaskan 0,5 lt minyak goreng dalam wajan diatas kompor dengan api sedang, setelah itu secara bertahap masukkan daging yang sudah ditiriskan goreng hingga kering warnya menjadi coklat muda, kemudian tiriskan. Pada proses ini masih manual, sehingga dikenalkan proses

penirisan menggunakan mesin. Pada proses ini masih manual, sehingga dikenalkan proses penirisan menggunakan mesin. Skema tahapan proses pembuatan abon pada gambar 1 berikut: 


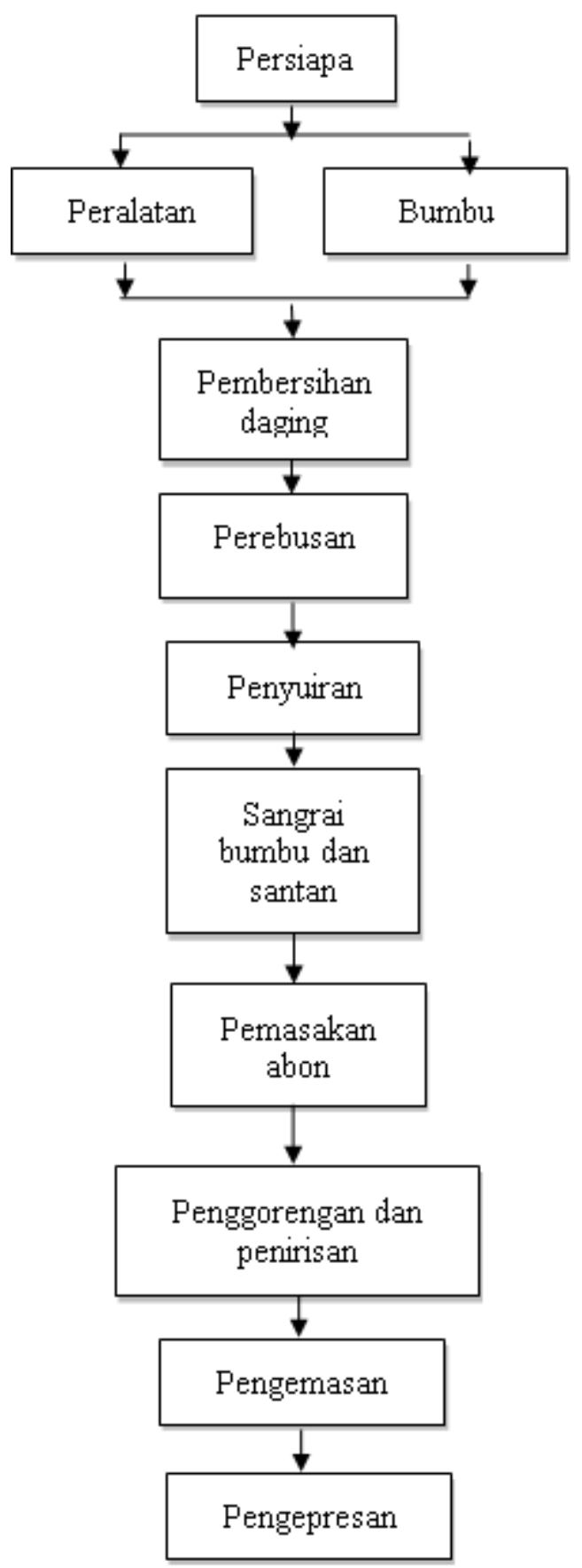

Gambar 1. Skema tahapan pembuatan abon

\section{Aspek menejemen}

Faktor yang berpengaruh terhadap perkembangan abon sapi adalah faktor internal dan ekternal/strategi SO (Putri, 2017). Berdasarkan hasil analisa menejemen untuk biaya investasi peralatan adalah sebesar Rp.6.500.000,- sedangkan total biaya operasional sebesar Rp.3.500.000,- , pendapatan asumsi terdapat 14 pak abon dengan harga rata rata Rp. 15.000,- maka selama satu bulan (30hari) didapatkan sebesar Rp.6.300.000,-. Keuntungan per bulan adalah total pendapatan-total biaya operasional yaitu Rp.6.300.000-3.500.000,- = Rp.2.800.000,- sedangkan pada skala industri keuntungan yang diperoleh selama satu bulan dapat mencapai Rp,- 18.216.812 (Yuliastuti, 2010). Sedangkan untuk menghitung lama balik modal adalah Total biaya investasi dibagi keuntungan yaitu Rp.6.500.000,$: 3.500 .000,-=$ sekitar 2 bulan. Sedangkan hasil analisa nilai tambah berdasarkan Hayami et, al 1987 didapatkan nilai sebesar Rp.73.333.33/kg, hal ini dipengaruhi oleh efisiensi penggunaan faktor produksi. Secara rinci perhitungan nilai tambah produksi abon terdapat pada tabel 1 berikut :

Tabel 1. Perhitungan Nilai Tambah Produksi Abon Metode Hayami.

\begin{tabular}{lc} 
Nomor Variabel Input,Output,Harga Nilai \\
\hline & \\
1.Produk hasilkan (Output)(kg/Proses) & 10 \\
2.Daging yang digunakan (Kg/proses) & 15 \\
3.Satuan jumlah Tenaga kerja(jam/proses) & 3 \\
4.Nilai Faktor konversi (0.2) & 0.66 \\
5.Nilai koefisien tenaga kerja & 0.2 \\
6.Harga produk (Output) (Rp/kg) & $350.000,-$ \\
7.Rata rata Upah (Rp/jam) & $10.000,-$ \\
8.Harga bahan baku(Rp/kg) & $100.000,-$ \\
9.Sumbangan input lain(Rp/kg Output) & $60.000,-$ \\
10.Nilai Output (Rp,-) & $233.333,-$ \\
11.a.Nilai Tambah (Rp.-) & $73.333,-$ \\
b.Rasio nilai tambah (\%) & $31.4 \%$ \\
12.a.Imbalan tenaga kerja (Rp,-) & $2000,-$ \\
b.Bagian tenaga kerja (\%) & $2.72 \%$ \\
13.a.Keuntungan (Rp,-) & 71.333 .33 \\
b.Tingkat Keuntungan (\%) & $97.27 \%$
\end{tabular}

Sumber : Hasi analisis data primer, 2018

\section{TARGET LUARAN}

Luaran dari program ini adalah :Menghasilkan produk Abon daging Sapi dengan kualitas hygienis dan performance yang lebih baik sehingga dapat berkembang dan memiliki segmentasi pasar yang lebih luas. Menghasilkan disain alat penggoreng dan penirisan serta mesin pencacah daging /suwir yang selama ini dilakukan secara 
manual, dan mempersiapkan tenaga terampil dari warga sekitar, sehingga produk yang dihasilkan menjadi lebih berkualitas dan berdaya saing.

\section{KESIMPULAN}

\section{Kesimpulan}

1. Berdasarkan hasil pendampingan dan penyuluahan selama proses pembuatan abon daging ini dapat disimpulkan bahwa :

2. Pada tahapan produksi hal yang perlu diperhatikan adalah penentuan mutu bahan baku daging (kesegaran) untuk menciptakanproduk abon yang berkualitas, untuk proses suwir daging apalagi dalam jumlah banyak diperlukan teknologi mesin suwir sehingga selainproses lebih cepat, mutu suwir daging seragam.

3. Pada proses menejemen, apalagi tertibnya transaksi data keuangan, dipe5rtlukan pula untuk mengetahui biaya investasi balik modal, dimana hasil analisis menunjukkan bahwa biaya balik modal adalah 2 (dua) bulan. Nilai tambah produksi abon sebesar Rp.73.333.33/kg, dimana hal ini dipengaruhi oleh efisiensi penggunaan biaya faktor produksi.

\section{Saran}

a. Perlu koordinasi dengan pihak pemotongan hewan dalam hal penyediaan bahan baku abon yang berkualitas baik.

b. Pada produksi abon dalam jumlah banyak, diperlukan mekanisasi baik dalam proses suwir, penggorengan, penirisan agar supaya produk abon yang dihasilkan seragam, hygiene, berkualitas dan efisien dalam proses produksi.

\section{REFERENSI}

Dinh, T. T. N., Legako, J. F., Miller, M. F., \& Brooks, J. C. (2018). Effects of USDA quality grade and cooking on water-soluble precursors of beef flavor. Meat Science, 146, 122-130.

Fianisa, R., Faridah,A. dan Gusnita,W., 2017. Pengaruh Substitusi Jantung Pisang Terhadap Kualitas Abon Daging sapi. Skripsi. Program Studi Pendidikan Kesejahteraan Keluarga. Jurusan Ilmu Kesejahteraan keluarga. Fakultas Pariwisata dan Perhotelan Universitas Negeri Padang.

Hayami Y, Kawagoe T, Morooka Y, Siregar M. 1987. Agricultural Marketing and Processing in Upland Java A Perspective From A Sunda Village. Bogor : CPGRT Centre.

Halid,S.A, dan Rahim,A. 2018. Sifat fisik, kimia dan aktivitas antioksidan abon daging ayam di kota palu. J-Agroland 25 (2) : 154-163, Agustus 2018. ISSN : 0854-641 X. E-ISSN : 2407-7607.

Kurniawati, E. Suryati,E. dan Wulandari,Z. 2010. Oksidasi lemak abon sapi selama penyimpanan pada suhu ruang. Skripsi. Departemen Ilmu Produksi dan teknologi Peternakan, Fakultas peternakan, Institut Pertanian Bogor.

Poulane, E. J., M.H. Rusunen and J. I. Vainionpaa.2001. Combined effects of $\mathrm{NaCl}$ and raw meat $\mathrm{pH}$ on waterholding in cooked sausage with and without added phosphate. Jurnal of Meat Science 58: 1-7.

Putri, T., Lamusa,A. 2017. Strategi Pengembangan Usaha Abon Daging Sapi Pada Industri " Citra Lestari Production" di Kota Palu.ej.Agrotekbis 5(4) :525-520, Agustus 2017.ISSN 2338-3011.

Susansi, A.; Purwanti,T. dan Kurniawati 2016. Pengaruh Jenis bahan pengisi Terhadap karakteristik Fisikokimia, Mikrobiologi dan Sensoris abon Udang. Jurnal Riset Teknologi Industri.Volume 10 No. 2 Desember 2016. 
Wahyuni,T.H; Rifai,J. dan Sibarani,P.N; 2015. Perbandingan Antara Substitusi Keluih ( Artocarpus Communis ) dan sukun ( Artocarpus Altilis ) Terhadap Kualitas Abon Sapi. Departemen peternakan Fakultas pertanian Universitas Sumatera Utara, Medan.

Yuliastuti.T, 2010. Analisis Nilai Tambah Pada Industri Abon "Ampael" di Kabupaten Boyolali. Skripsi. Fakultas Pertanian Universitas Sebelas Maret, Surakarta. 